\title{
ACTG1 wt Allele
}

National Cancer Institute

\section{Source}

National Cancer Institute. ACT G1 wt Allele. NCI Thesaurus. Code C150160.

Human ACT G1 wild-type allele is located in the vicinity of $17 q 25.3$ and is approximately 44 $\mathrm{kb}$ in length. This allele, which encodes actin, cytoplasmic 2 protein, is involved in cell motility. Mutation of the gene is associated with autosomal dominant non-syndromic sensorineural progressive hearing loss and Baraitser-Winter syndrome. 